Original Research

\title{
Effects of PGPR Co-inoculation on Growth, Phosphorus Nutrition and Phosphatase/Phytase Activities of Faba Bean under Different Phosphorus Availability Conditions
}

\author{
Noura Bechtaoui, Anas Raklami, Loubna Benidire, Abdel-ilah Tahiri, \\ Michael Göttfert, Khalid Oufdou* \\ Laboratory of Microbial Biotechnologies, Agrosciences and Environment (BioMAgE), Faculty of Sciences, \\ Semlalia, Cadi Ayyad University, Marrakech, Morocco
}

Received: 11 April 2019

Accepted: 27 June 2019

\begin{abstract}
Plant growth promoting rhizobacteria (PGPR) may improve crop yield and reduce or optimize the use of chemical fertilizers. We investigated the effect of co-inoculation on growth, phosphorus nutrition, and phosphatase-phytase activities of Vicia faba under different phosphorus availability conditions. The studied strains possess several PGPR traits such as nitrogen fixation ability, solubilization of phosphate and potassium, and production of exopolysaccharides, auxins, and siderophores. Based on their 16S rDNA sequences, the strains were identified as Rahnella aquatilis (PGP30), Pseudomonas brassicacearum (PGP291) and Rhizobium sp. (RhOF57A). In a greenhouse experiment, plants were inoculated with an individual strain or co-inoculated with two strains in addition to uninoculated controls. Each setup was supplemented either with tricalcium phosphate $\mathrm{Ca}_{3}\left(\mathrm{PO}_{4}\right)_{2}$ (TCP treatment) or irrigated with potassium phosphate $\mathrm{KH}_{2} \mathrm{PO}_{4}\left(\mathrm{PO}_{4}\right.$ treatment). Regardless of the applied phosphorus source, co-inoculation significantly increased biomass and phosphorus concentrations in plants as well as in bean pods. Moreover, especially co-inoculation increased phosphatase-phytase activities in roots supplemented with tricalcium phosphate. This study suggests that co-inoculation of plants is a means to prevent phosphorus limitation and for judicious use of chemical fertilizers.
\end{abstract}

Keywords: PGPR, rhizobia, phosphatase-phytase, Vicia faba, phosphate solubilization

*e-mail: oufdou@uca.ma 


\section{Introduction}

After nitrogen, phosphorus is the most limiting nutrient for plant growth. Depending on the soil $\mathrm{pH}$, phosphorus is sequestered and precipitated by reactions with cations, especially iron, aluminum, calcium, and plants absorbing only a small amount of available phosphorus $[1,2]$. For this reason, a significant amount of phosphate fertilizer is required to correct phosphorus deficiency in the soil. Extensive fertilizer use might negatively affect soil microbial function and plant yield [3]. Moreover, the cost of phosphate fertilizers has rapidly increased due to the decrease in highquality phosphate reserves $[4,5]$. Therefore, the use of phosphate fertilizers must be as judicious as possible. Plant growth promoting rhizobacteria (PGPR) actively participate in the transformation of phosphate in the soil and make phosphorus available to the plant. The use of PGPR solubilizing soil phosphate in agronomic practices is advocated for several reasons. They improve soil fertility and increase crop yield through the increase of nutrient availability [6]. They do not pollute the environment, do not affect soil health, protect plants against phytopathogens and low-cost technology is used for their production [7]. Nitrogen-fixing bacteria may be the most promising PGPR group, due to their ability to improve nitrogen nutrition in either symbiotic or non-symbiotic interactions. Co-inoculation with such strains constitutes an alternative approach to improving nitrogen and phosphorus nutrition of crops, especially in deficient soils. For example, co-inoculation with rhizobia and Bacillus sp. significantly increased the yield of wheat [8]. Similarly, co-inoculation with Rhizobium leguminosarum and a Pseudomonas strain stimulated plant growth and yield of chickpea more than the inoculation with one strain only [9].

The majority of Mediterranean soils are characterized by low phosphorus availability, which often limits legume production. Plants have developed several strategies to escape soil phosphorus limitation. They can modify the architecture of their roots to optimize phosphorus acquisition from the soil. They can also hydrolyze or mobilize phosphate compounds by excreting organic acids and acid phosphatase [10, 11]. Symbiotic associations with mycorrhizal fungi enhance the uptake of soil nutrients such as phosphorus and potassium [12]. Some symbiotic rhizobial combinations improve phosphorus availability of plants through the excretion of nodule phosphatases [13].

Improving the adaptation of faba bean to phosphorusdeficient soils by inoculation with native PGPR strains might be an appropriate agricultural practice. The main objectives of this study were: (a) to determine whether complex phosphate fertilizer (TCP) coupled with bacterial inoculants would produce levels of growth, yield and nutrient uptake equivalent to those obtained with available phosphorus fertilizers $\left(\mathrm{KH}_{2} \mathrm{PO}_{4}\right)$, (b) and to compare the impact of individual inoculation and coinoculation on the activities of enzymes (phosphatase and phytase) that are involved in plant adaptation to phosphorus stress conditions.

\section{Material and Methods}

\section{Isolation of Phosphate-Solubilizing Bacteria}

Samples of the rhizospheric soils of faba bean were taken from the cultivated fields of the Marrakech region (Ait Ourir, Morocco). $10 \mathrm{~g}$ of soil samples were transferred into $90 \mathrm{ml}$ of sterile physiological water with continuous shaking (180 rpm). $100 \mu \mathrm{l}$ of the soil solution were plated on agar medium of the National Botanical Research Institute's phosphate medium devoid of yeast extract (NBRIY) [14] containing $5 \mathrm{~g}$ of $\mathrm{Ca}_{3}\left(\mathrm{PO}_{4}\right)_{2}$ (tricalcium phosphate: TCP) as a source of complex phosphate. The incubation of the plates was carried out at $28^{\circ} \mathrm{C}$ for $48 \mathrm{~h}$ to $72 \mathrm{~h}$. Strains producing a clear halo on the NBRIY medium were counted and purified by repeated streaking on the NBRIY medium. As a final step, the strains were purified on TSA (Trypticase Soy Agar) medium and were stored in $25 \%$ glycerol at $-20^{\circ} \mathrm{C}$. Rhizobia were isolated from nodules of faba bean as described by Benidire et al. [15].

\section{PGPR Activities and Molecular Identification of Rhizobacterial Strains}

The rhizobacterial strains were tested for several PGPR activities, such as the solubilization of tricalcium phosphate in an agar medium, which was calculated and presented as diameter halo $(\mathrm{cm}) /$ diameter colony $(\mathrm{cm})$ ratio $(\mathrm{DH} / \mathrm{DC})$. In the liquid medium, the $\mathrm{pH}$ and the $\mathrm{P}$ available were calculated for each strain as described by Maghraoui et al. [16]. Other PGPR traits were also conducted, including potassium solubilization (according to Alikhani et al. [17]), siderophore [18], exopolysaccharide [19] and indole acetic acid production [20], as well as nitrogen fixation $\left(\mathrm{N}_{2}\right)$ [21]. The molecular identification of the tested rhizobacterial strains was carried out as described by Benidire et al. [15].

\section{Plant Material and Growth Condition}

We used for the greenhouse experiment the commercial Aguadulce variety that is widely used in Morocco. One hundred and ten homogenous bean seeds were service-sterilized with $1 / 3$-diluted $12 \%$ sodium hypochlorite solution. After a series of successive rinses with sterile distilled water, the seeds were germinated for $72 \mathrm{~h}$ at $28^{\circ} \mathrm{C}$. The inocula of the bacterial strains PGP30, PS291 and RhOF57A were prepared by growing each strain in trypticase soy broth or YEM broth (for rhizobia) at $28^{\circ} \mathrm{C}$ for 2 to 3 days. Bacterial cells were harvested, washed several times with sterile physiological water $(\mathrm{NaCl} 9 \mathrm{~g} / \mathrm{l})$ and resuspended in the adequate volume of sterile physiological water to obtain a final $\mathrm{OD}=1$ at $\lambda=600 \mathrm{~nm}$ (approximately $10^{9} \mathrm{CFU} / \mathrm{ml}$ ). The experiment 
included four treatments of faba bean: i) inoculation with PGP291 alone; ii) inoculation with PGP30 alone; iii) co-inoculation with PGP291+RhOF57A; iv) and coinoculation with PGP30+RhOF57A. For inoculation, the germinated seeds were submerged for $30 \mathrm{~min}$ in the inoculum. For co-inoculation, strains were mixed at a $1: 1 \mathrm{~V} / \mathrm{V}$ ratio. Previously disinfected two-liter pots were filled with damp perlite and inoculated seeds were then transferred into the pots (two seeds/pot). Second and third inoculation of the roots with $2 \mathrm{ml}$ of every inoculum were done two and three weeks after planting of the seedlings, respectively.

We used $\mathrm{KH}_{2} \mathrm{PO}_{4}$ as an available source of phosphorus $\left(\mathrm{PO}_{4}\right.$ treatments) and tricalcium phosphate $\left(\mathrm{Ca}_{3}\left(\mathrm{PO}_{4}\right)_{2}\right)$ as a complex source of phosphorus (TCP treatments). Tricalcium phosphate was supplied at a quantity of $1 \mathrm{~g} / \mathrm{seed}$. To irrigate plants of the $\mathrm{PO}_{4}$ treatment, $0.5 \mathrm{~g} \mathrm{KH} \mathrm{PO}_{4} / \mathrm{l}$ of nutrient solution was used. Control treatments without inoculation were also conducted for this experiment: Control 1 (C1): plants were grown under the same conditions without any source of phosphorus; control 2 (C2): plants were supplemented with tricalcium phosphate; control 3 (C3): plants were irrigated with $\mathrm{KH}_{2} \mathrm{PO}_{4}$ in the nutrient solution. The pots were placed in individual trays in the greenhouse of the Semlalia Faculty of Sciences (Marrakech, Morocco) under natural conditions characterized by a temperature between 20 and $25^{\circ} \mathrm{C}$, $47 \%$ relative humidity and the duration of the day was 11 hours. The inoculated pots with PGP30 and PGP291 were separated from the RhOF57A pots and the co-inoculation treatments. The control pots were separated from inoculation treatments. Plants were irrigated two or three times with $250 \mathrm{ml}$ of the nutrient solution of Rigaud and Puppo [22], according to their need. The harvest was carried out after 4 months at the seed maturity stage. Roots were thoroughly rinsed with tap water and separated from the shoots. Shoots and roots of faba bean were dried at $70^{\circ} \mathrm{C}$ for $48 \mathrm{~h}$ to determine their dry weight. Bean pods were also collected and dried $\left(70^{\circ} \mathrm{C}, 48 \mathrm{~h}\right)$. For measuring phosphorus concentrations, plants (shoots and roots) and bean pods were ground and ashed at $550^{\circ} \mathrm{C} .3 \mathrm{ml}$ of $\mathrm{HCl}$ $(6 \mathrm{~N})$ were added to every sample and directly placed on a hot plate for evaporation at $330^{\circ} \mathrm{C}$ for at least one hour. Finally, $3 \mathrm{ml}$ of hot distilled water were added. The obtained solutions were filtered using Whatman paper of $0.45 \mu \mathrm{m}$ pore size, and the extracts were added to $20 \mathrm{ml}$ of distilled water and stored at $4^{\circ} \mathrm{C}$ until measurement of the phosphorus concentration as described by Olsen and Sommers [23]. The results are given in $\mathrm{mg}$ of phosphate per $g$ of dry matter.

\section{Phosphatase-Phytase Activities}

$0.2 \mathrm{~g}$ of frozen fresh roots of each plant were ground in an Eppendorf tube containing $500 \mu$ of acetate-buffer (0.1 M pH 5.6), 33\% of Polyvinylpyrrolidone (PVP) and $5 \mu$ of $\beta$-mercaptoethanol. The tube was centrifuged at
$13000 \mathrm{~g}$ at $4^{\circ} \mathrm{C}$ for $30 \mathrm{~min} .100 \mu \mathrm{l}$ of the supernatant were taken for phosphatase-phytase activity assays. The phosphatase activity in the roots was measured using p-nitrophenyl phosphate as substrate, according to the method described by Asmar and Gissel-Nielsen [24]. $100 \mu \mathrm{l}$ of the root extract were incubated at $37^{\circ} \mathrm{C}$ for $30 \mathrm{~min}$ in a mixture of $200 \mu \mathrm{l}$ acetate-buffer and $200 \mu \mathrm{l}$-nitrophenyl phosphate (p-NPP). The reaction was stopped by adding $1 \mathrm{ml}$ of $\mathrm{NaOH}(0.5 \mathrm{~N})$. The acid phosphatase activity was determined by measuring the formation of para-nitrophenolate at $410 \mathrm{~nm}$ wavelength. The result is given in nmole of para-nitrophenol (PNP) product per min per $g$ of fresh roots. Sodium phytate was used for measuring phytase activity. In brief, $100 \mu \mathrm{l}$ of root extract were added to a mixture containing $0.1 \mathrm{M}$ sodium acetate buffer ( $\mathrm{pH} \mathrm{5)}$ and $1 \mathrm{mM}$ sodium phytate. The mixture was incubated for $90 \mathrm{~min}$ at $37^{\circ} \mathrm{C}$ and the reaction was stopped by the addition of $0.5 \mathrm{ml}$ $10 \%$ of $\mathrm{HCl}$. The mixture was centrifuged for $5 \mathrm{~min}$ at $13000 \mathrm{rpm}$. The supernatant was analyzed for $\mathrm{Pi}$ liberation [25]. The phytase activity of the extract was determined by spectrophotometry at $\lambda=630 \mathrm{~nm}$.

\section{Statistical Analysis}

We used a completely random block assay design. Registered growth values of strains (in vitro tests) were means of three replicates per treatment. Regarding the greenhouse experiment, results were means of eight biological replicates. All results were subjected to analysis of variance, with a Student-Newman-Keuls (SNK) method for the comparison of means using SPSS software. Analysis of variance (ANOVA) was performed for comparison of means. Standard errors (SE) were also calculated and are presented in the tables. Biomass values, enzyme activities and phosphorus concentrations and their correlation with treatments were used for principal component analyses (PCA) using XLStat software.

\section{Results and Discussion}

\section{PGPR Activities and Molecular Identification of Rhizobacterial Strains}

The strains differed in their solubilization capacity of tricalcium phosphate on agar plates (Table 1). Halo formation for PGP30 began within three days of incubation, while PGP291 and RhOF57A began to solubilize complex phosphate and produce a clear halo after about 10 days of incubation. After 15 days of incubation, all strains showed a huge clear zone around their colonies. PGP30 exhibited the highest DH/DC value (Table 1), suggesting that PGP30 is the most powerful phosphate solubilizer of the three strains. However, in liquid medium PGP30 released the smallest amount of available phosphorus within 4 days, while RhOF57A recorded the highest quantity 
Table 1. Different plant growth-promoting activities of the three bacterial strains.

\begin{tabular}{|c|c|c|c|c|}
\hline \multicolumn{2}{|l|}{ Trait } & PGP30 & PGP291 & RhOF57A \\
\hline \multirow{3}{*}{$\begin{array}{l}\text { Phosphate solubilization } \\
\text { (DH/DC) }\end{array}$} & 3 days & $1.76 \pm 0.06^{\mathrm{a}}$ & - & - \\
\hline & 10 days & $2.63 \pm 0.13^{\mathrm{a}}$ & $1.46 \pm 0.02^{\mathrm{c}}$ & $1.6 \pm 0.05^{\mathrm{b}}$ \\
\hline & 15 days & $2.86 \pm 0.14^{\mathrm{a}}$ & $1.29 \pm 0.04^{b}$ & $1.12 \pm 0.05^{\mathrm{c}}$ \\
\hline \multicolumn{2}{|c|}{ Auxin production $(\mu \mathrm{g} / \mathrm{ml})$} & $13.52 \pm 1.26^{\mathrm{c}}$ & $22.58 \pm 2.45^{\mathrm{b}}$ & $217.56 \pm 4.05^{\mathrm{a}}$ \\
\hline \multicolumn{2}{|c|}{$\begin{array}{l}\text { Exopolysaccharide production } \\
(\mu \mathrm{g} \text { of Congo Red/OD } 600)\end{array}$} & $110.46 \pm 4.79^{c}$ & $147.78 \pm 4.79^{\mathrm{b}}$ & $894.06 \pm 1.67^{\mathrm{a}}$ \\
\hline \multicolumn{2}{|c|}{ Siderophore production } & $(-)$ & $(+)$ & $(+)$ \\
\hline \multicolumn{2}{|c|}{ Potassium solubilization } & $(-)$ & $(-)$ & $(+)$ \\
\hline \multicolumn{2}{|c|}{ Nitrogen fixation } & $(+)$ & $(+)$ & $(+)$ \\
\hline
\end{tabular}

Means \pm standard errors within the same line followed by different letters are significantly different at $\mathrm{p}<0.05$ according to the SNK test. Phosphate solubilization (DH/DC): Average of halo diameter $(\mathrm{cm}) /$ Average of colony diameter $(\mathrm{cm})$; Siderophore production $(+)$ : Change of medium coloration from blue to orange; Potassium solubilization $(+)$ : Halo formation in the medium; Free nitrogen fixation $(+)$ : Bacterial development without nitrogen source.

of available phosphorus $(2.25 \mathrm{mg} / \mathrm{l}$ at $72 \mathrm{~h})$. For strains RhOF57A and PGP291, we noted a decrease in $\mathrm{pH}$ values in the first $24 \mathrm{~h}$, which concurred with the release of significant amounts of available phosphorus in the broth (Table 2). Halo formation in agar plates and the $\mathrm{pH}$ drop in the liquid medium might be due to the production of organic acids. They may chelate the metal associated with phosphorus and hence make the phosphorus available [26]. RhOF57 might use both organic acids and exopolysaccharides for complex phosphate mobilization as was suggested for Bacillus marisflavi by Prabhu et al. [27]. Indeed, RhOF57A showed a massive exopolysaccharide production (Table 1). Moreover, the strains showed other PGPR traits such as nitrogen fixation capacity and the release of indole acetic acid (IAA) with the highest amount recorded for RhOF57A (217.56 $\mu \mathrm{g} / \mathrm{ml})$. According to the blue agar CAS assay, strains RhOF57A and PGP291 were able to produce siderophores, and only RhOF57A had the ability to mobilize complex potassium (Table 1).

Thus, these strains might support plant growth by different mechanisms: i) the production of IAA; a phytohormone that induces plant development and increases the total root surface area for a better nutrient uptake, ii) the production of siderophores responsible for iron chelation and the control of plant pathogens, and iii) the correction of a nutrient unbalance via nitrogen fixation and/or mobilization of complexed minerals such as potassium and phosphate [28]. Accordingly, the studied strains are considered plant growth-promoting rhizobacteria and could be used for plant inoculation.

Table 2. $\mathrm{pH}$ values and the amount of available phosphorus $(\mathrm{mg} / \mathrm{l})$ released by phosphate-solubilizing strains in NBRIY broth containing tricalcium phosphate.

\begin{tabular}{|c|c|c|c|c|c|c|}
\hline \multicolumn{7}{|c|}{$\mathrm{pH}$ values during incubation time } \\
\hline Strain & $0 \mathrm{~h}$ & $24 \mathrm{~h}$ & $48 \mathrm{~h}$ & $72 \mathrm{~h}$ & $96 \mathrm{~h}$ & $120 \mathrm{~h}$ \\
\hline Control & $7.19 \pm 0.01^{\mathrm{a}}$ & $7.19 \pm 0.03^{\mathrm{a}}$ & $6.70 \pm 0.04^{\mathrm{b}}$ & $6.96 \pm 0.04^{\mathrm{a}}$ & $6.43 \pm 0.02^{\mathrm{c}}$ & $5.91 \pm 0.01^{\mathrm{d}}$ \\
\hline PGP30 & $7.20 \pm 0.14^{\mathrm{a}}$ & $7.20 \pm 0.10^{\mathrm{a}}$ & $5.53 \pm 0.08^{\mathrm{b}}$ & $7.06 \pm 0.24^{\mathrm{a}}$ & $7.24 \pm 0.03^{\mathrm{a}}$ & $7.25 \pm 0.03^{\mathrm{a}}$ \\
\hline PGP291 & $7.19 \pm 0.09^{\mathrm{a}}$ & $4.8 \pm 0.02^{\mathrm{d}}$ & $4.38 \pm 0.10^{\mathrm{e}}$ & $5.89 \pm 0.01^{\mathrm{c}}$ & $5.82 \pm 0.03^{\mathrm{c}}$ & $6.13 \pm 0.03^{\mathrm{b}}$ \\
\hline RhOF57A & $7.11 \pm 0.01^{\mathrm{a}}$ & $4.20 \pm 0.04^{\mathrm{e}}$ & $4.58 \pm 0.04^{\mathrm{d}}$ & $6.35 \pm 0.10^{\mathrm{b}}$ & $4.48 \pm 0.03^{\mathrm{d}}$ & $5.25 \pm 0.17^{\mathrm{c}}$ \\
\hline \multicolumn{7}{|c|}{ P available values in the broth $(\mathrm{mg} / 1)$ after the incubation time indicated above } \\
\hline Control & - & - & - & - & - & - \\
\hline PGP30 & $0.013 \pm 0.00^{\mathrm{d}}$ & $0.94 \pm 0.05^{\mathrm{a}}$ & $0.62 \pm 0.15^{\mathrm{b}}$ & $0.81 \pm 0.12^{\mathrm{a}}$ & $0.46 \pm 0.13^{\mathrm{c}}$ & $0.015 \pm 0.02^{\mathrm{d}}$ \\
\hline PGP291 & $0.011 \pm 0.00^{\mathrm{d}}$ & $1.84 \pm 0.14^{\mathrm{a}}$ & $1.15 \pm 0.15^{\mathrm{c}}$ & $1.54 \pm 0.10^{\mathrm{b}}$ & $0.89 \pm 0.25^{\mathrm{c}}$ & $0.012 \pm 0.01^{\mathrm{d}}$ \\
\hline RhOF57A & $0.011 \pm 0.00^{\mathrm{c}}$ & $2.02 \pm 1^{\mathrm{a}}$ & $1.17 \pm 0.3^{\mathrm{b}}$ & $2.25 \pm 0.01^{\mathrm{a}}$ & $1.15 \pm 0.3^{\mathrm{b}}$ & $0.011 \pm 0.04^{\mathrm{c}}$ \\
\hline
\end{tabular}

Means \pm standard errors within the same line followed by different letters are significantly different at $\mathrm{p}<0.05$ according to the SNK test. 


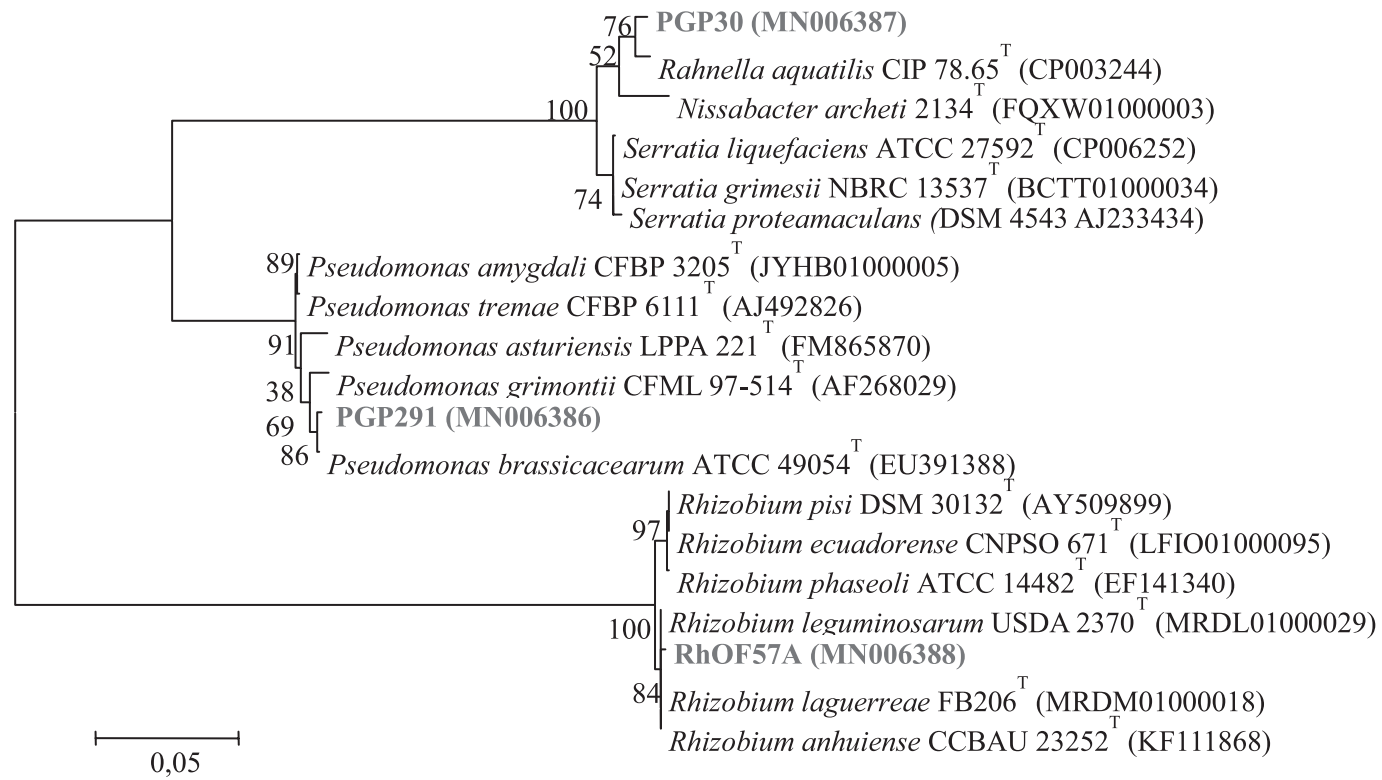

Fig. 1. Maximum likelihood phylogenetic tree of strains PGP30, PGP291 and RhOF57A based on 16S rDNA gene sequences, showing their position with regard to related species. Bootstrap values based on 1500 replications are given at branch points. Accession numbers are given in parenthesis. Scale bar: substitutions per nucleotide position.

Molecular identification revealed that PGP30 is similar to Rahnella aquatilis, PGP291 is closest to Pseudomonas brassicacearum, while RhOF57A is a Rhizobium sp. (Fig. 1). The 16S rDNA nucleotide sequences determined in this work were submitted to the GenBank database and have been assigned the accession numbers MN006387, MN006386, and MN006388 for PGP30, PGP291, and RhOF57A, respectively.

Table 3. Effect of bacterial inoculation on plant parameters with different phosphorus supplies.

\begin{tabular}{|c|c|c|c|c|c|c|}
\hline Treatment & Plant length $(\mathrm{cm})$ & $\begin{array}{l}\text { Shoot dry } \\
\text { weight }(g)\end{array}$ & $\begin{array}{c}\text { Root dry } \\
\text { weight }(\mathrm{g})\end{array}$ & $\begin{array}{l}\text { Root } / \text { shoot } \\
\text { ratio }\end{array}$ & $\begin{array}{l}\text { Pod dry weight } \\
\text { (g) }\end{array}$ & $\begin{array}{c}\text { Increase of bean pod } \\
\text { dry weight over control } \\
(\%)\end{array}$ \\
\hline $\mathrm{C} 1$ & $70.33 \pm 1.15^{\mathrm{d}}$ & $2.96 \pm 0.24^{\mathrm{e}}$ & $2.65 \pm 0.15^{\mathrm{a}}$ & $0.89 \pm 0.02^{\mathrm{a}}$ & $(*)$ & - \\
\hline \multicolumn{7}{|c|}{ TCP } \\
\hline $\mathrm{C} 2$ & $90 \pm 1.99^{c}$ & $3.15 \pm 0.2^{\mathrm{e}}$ & $2.47 \pm 0.1^{\mathrm{a}}$ & $0.78 \pm 0.12^{\mathrm{a}}$ & $0.13 \pm 0.02^{\mathrm{d}}$ & - \\
\hline $\operatorname{Tr} 1$ & $93.67 \pm 1.7^{\mathrm{b}}$ & $4.50 \pm 0.24^{c}$ & $2.93 \pm 0.19^{\mathrm{a}}$ & $0.65 \pm 0.08^{\mathrm{a}}$ & $0.22 \pm 0.04^{\mathrm{c}}$ & 69.23 \\
\hline $\operatorname{Tr} 2$ & $96.67 \pm 2.4^{b}$ & $4.60 \pm 0.23^{\mathrm{c}}$ & $2.53 \pm 0.32^{\mathrm{a}}$ & $0.55 \pm 0.04^{\mathrm{a}}$ & $0.25 \pm 0.03^{\mathrm{c}}$ & 92.31 \\
\hline $\operatorname{Tr} 3$ & $98.33 \pm 1.1^{\mathrm{b}}$ & $6.71 \pm 0.23^{b}$ & $0.97 \pm 0.16^{\mathrm{b}}$ & $0.14 \pm 0.09^{c}$ & $0.56 \pm 0.02^{\mathrm{b}}$ & 330.76 \\
\hline $\operatorname{Tr} 4$ & $105.17 \pm 1.7^{\mathrm{a}}$ & $7.72 \pm 0.25^{\mathrm{a}}$ & $0.98 \pm 0.16^{\mathrm{b}}$ & $0.12 \pm 0.05^{\mathrm{c}}$ & $0.68 \pm 0.01^{\mathrm{a}}$ & 423.07 \\
\hline \multicolumn{7}{|c|}{$\mathrm{PO}_{4}$} \\
\hline $\mathrm{C} 3$ & $89 \pm 2.41^{\mathrm{c}}$ & $3.82 \pm 0.12^{\mathrm{d}}$ & $1.98 \pm 0.18^{\mathrm{a}}$ & $0.51 \pm 0.06^{\mathrm{ab}}$ & $0.15 \pm 0.02^{\mathrm{c}}$ & - \\
\hline $\operatorname{Tr} 1$ & $95 \pm 2.22^{\mathrm{b}}$ & $4.38 \pm 0.19^{c}$ & $2.32 \pm 0.16^{\mathrm{a}}$ & $0.52 \pm 0.03^{\mathrm{a}}$ & $0.18 \pm 0.03^{\mathrm{c}}$ & 20 \\
\hline $\operatorname{Tr} 2$ & $97 \pm 1.68^{\mathrm{b}}$ & $4.97 \pm 0.19^{c}$ & $2.33 \pm 0.18^{\mathrm{a}}$ & $0.46 \pm 0.01^{\mathrm{b}}$ & $0.20 \pm 0.03^{\mathrm{c}}$ & 33.33 \\
\hline $\operatorname{Tr} 3$ & $100 \pm 1.81^{b}$ & $6.82 \pm 0.13^{b}$ & $0.55 \pm 0.15^{\mathrm{c}}$ & $0.08 \pm 0.07^{\mathrm{c}}$ & $0.60 \pm 0.04^{b}$ & 300 \\
\hline $\operatorname{Tr} 4$ & $110 \pm 2.80^{\mathrm{a}}$ & $7.42 \pm 0.23^{\mathrm{a}}$ & $0.88 \pm 0.06^{\mathrm{b}}$ & $0.11 \pm 0.08^{\mathrm{c}}$ & $0.75 \pm 0.02^{\mathrm{a}}$ & 400 \\
\hline
\end{tabular}

C1: uninoculated control plants without phosphorus source; C2: uninoculated control plants supplemented with tricalcium phosphate; C3: uninoculated control plants supplemented with $\mathrm{KH}_{2} \mathrm{PO}_{4}$; $\operatorname{Tr} 1$ : plants inoculated with PGP291; $\operatorname{Tr} 2$ :

plants inoculated with PGP30; Tr3: plants inoculated with PGP291+RhOF57A; Tr4: plants inoculated with PGP30+RhOF57A. (*): No pod development for $\mathrm{C} 1$ plants. Means ( \pm standard errors) within the same column followed by different letters are significantly different according to the Student, Newmann, Keuls test at $\mathrm{p}<0.05$. 
Table 4. Effect of bacterial inoculation on phosphorus concentration, phytase and phosphatase activities in faba bean plants with different phosphorus supply.

\begin{tabular}{|c|c|c|c|c|}
\hline Treatment & $\begin{array}{l}\text { Plant phosphorus } \\
\text { concentration } \\
\text { (mg/g of dry matter) }\end{array}$ & $\begin{array}{l}\text { Bean pod phosphorus } \\
\text { concentration } \\
\text { (mg/g of dry matter) }\end{array}$ & $\begin{array}{c}\text { Phosphatase } \\
\text { (nmole of } \mathrm{Pi} / \mathrm{min} / \mathrm{g} \\
\text { of fresh matter) }\end{array}$ & $\begin{array}{l}\text { Phytase (nmole of Pi/ } \\
\mathrm{min} / \mathrm{g} \text { of fresh matter) }\end{array}$ \\
\hline $\mathrm{C} 1$ & $5.78 \pm 0.05^{\mathrm{f}}$ & $(*)$ & $40.95 \pm 2.05^{\mathrm{f}}$ & $30 \pm 2^{\mathrm{f}}$ \\
\hline \multicolumn{5}{|c|}{ TCP } \\
\hline $\mathrm{C} 2$ & $6.1 \pm 0.25^{f}$ & $3.61 \pm 0.42^{\mathrm{d}}$ & $35.77 \pm 4.63^{\mathrm{f}}$ & $21 \pm 6.2^{\mathrm{f}}$ \\
\hline $\operatorname{Tr} 1$ & $11.8 \pm 0.21^{\mathrm{d}}$ & $5.69 \pm 0.30^{c}$ & $83.77 \pm 5.61^{\mathrm{d}}$ & $30 \pm 2.2^{\mathrm{f}}$ \\
\hline $\operatorname{Tr} 2$ & $15.73 \pm 0.25^{\mathrm{c}}$ & $6.90 \pm 0.30^{\mathrm{b}}$ & $96.71 \pm 7.36^{\mathrm{d}}$ & $109 \pm 3.2^{\mathrm{c}}$ \\
\hline $\operatorname{Tr} 3$ & $17.14 \pm 0.24^{\mathrm{b}}$ & $8.49 \pm 0.31^{\mathrm{a}}$ & $118.57 \pm 3.68^{c}$ & $140 \pm 4.4^{b}$ \\
\hline $\operatorname{Tr} 4$ & $19.12 \pm 0.10^{\mathrm{a}}$ & $8.75 \pm 0.34^{\mathrm{a}}$ & $180.64 \pm 5.61^{\mathrm{a}}$ & $208 \pm 2^{\mathrm{a}}$ \\
\hline \multicolumn{5}{|c|}{$\mathrm{PO}_{4}$} \\
\hline $\mathrm{C} 3$ & $8 \pm 0.23 e$ & $2.89 \pm 0.19^{\mathrm{e}}$ & $27.96 \pm 2.56^{g}$ & $12 \pm 3^{g}$ \\
\hline $\operatorname{Tr} 1$ & $12.31 \pm 0.28^{\mathrm{d}}$ & $4.21 \pm 0.2^{\mathrm{d}}$ & $56.3 \pm 2.23^{\mathrm{e}}$ & $24 \pm 4^{\mathrm{f}}$ \\
\hline $\operatorname{Tr} 2$ & $16.77 \pm 0.10^{\mathrm{b}}$ & $4.90 \pm 0.33^{\mathrm{d}}$ & $91.51 \pm 9.30^{\mathrm{d}}$ & $39 \pm 2^{\mathrm{e}}$ \\
\hline $\operatorname{Tr} 3$ & $18.60 \pm 0.58^{\mathrm{a}}$ & $8.85 \pm 0.31^{\mathrm{a}}$ & $110.75 \pm 4.27^{\mathrm{c}}$ & $96 \pm 1.4^{\mathrm{d}}$ \\
\hline $\operatorname{Tr} 4$ & $19.42 \pm 0.24^{\mathrm{a}}$ & $9.51 \pm 0.37^{\mathrm{a}}$ & $140.60 \pm 9.09^{b}$ & $133 \pm 6.2^{b}$ \\
\hline
\end{tabular}

C1: uninoculated control plants without phosphorus source; $\mathrm{C} 2$ : uninoculated control plants supplemented with tricalcium phosphate; C3: uninoculated control plants supplemented with $\mathrm{KH}_{2} \mathrm{PO}_{4}$; Tr1: plants inoculated with PGP291; Tr2: plants inoculated with PGP30; Tr3: plants inoculated with PGP291+RhOF57A; Tr4: plants inoculated with PGP30+RhOF57A. $\left(^{*}\right)$ : No pod development for $\mathrm{C} 1$ plants. Means ( \pm standard errors) within the same column followed by different letters are significantly different according to the Student, Newmann, Keuls test at $\mathrm{p}<0.05$.

Biplot (axes F1 and F2 : $92.12 \%)$

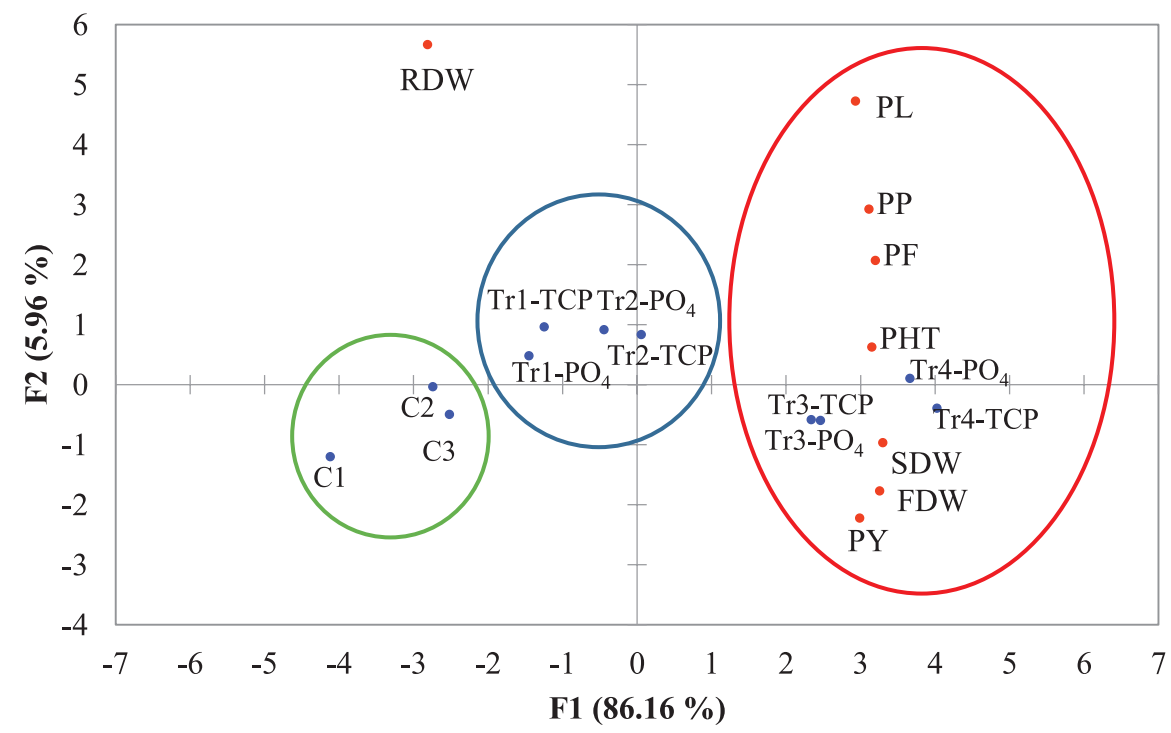

Fig. 2. Principal component analyses (PCA) of faba bean submitted to different treatments given in blue: $\mathrm{C} 1$ : plants without inoculation and without phosphorus source; $\mathrm{C} 2$ : plants grown without inoculation and supplemented with tricalcium phosphate; C3: plants without inoculation and irrigated with $\mathrm{KH}_{2} \mathrm{PO}_{4}$; Tr1-TCP: plants inoculated with PGP291 and supplemented with tricalcium phosphate; Tr2-TCP: plants inoculated with PGP30 and supplemented with tricalcium phosphate; Tr3-TCP: plants inoculated with PGP291+RhOF57A and supplemented with tricalcium phosphate; Tr4-TCP: plants inoculated with PGP30+RhOF57A and supplemented with tricalcium phosphate; Tr1-PO4: plants inoculated with PGP291 and irrigated with $\mathrm{KH}_{2} \mathrm{PO}_{4}$; $\mathrm{Tr} 2-\mathrm{PO}_{4}$ : plants inoculated with PGP30 and irrigated with $\mathrm{KH}_{2} \mathrm{PO}_{4}$; Tr3- $-\mathrm{PO}_{4}$ : plants inoculated with PGP291+RhOF57A and irrigated with $\mathrm{KH}_{2} \mathrm{PO}_{4}$; $\operatorname{Tr} 4-\mathrm{PO}_{4}$ : plants inoculated with PGP30+RhOF57A and irrigated with $\mathrm{KH}_{2} \mathrm{PO}_{4}$. Biomass, yield and nutrient concentrations are represented in red. PL: plant length; SDW: shoot dry weight; RDW: root dry weight; FDW: fruit pod dry weight; PP: phosphorus concentration in plants; PF: phosphorus concentration in fruit; PY: phytase activity in plants; PHT: phosphatase activity in plants. 


\section{Plant Nutrition and Yield Improvement}

Plant length and shoot dry weight of inoculated faba bean plants were significantly higher than for uninoculated controls (Table 3). Highest values were obtained for the co-inoculation with PGP30+RhOF57A. In contrast, root dry weights and root/shoot ratios of co-inoculated plants showed the lowest values (Table 3). Balemi and Negisho [12] reported that the higher root/shoot ratio is often a sign of growth under phosphorus limitations. The reduction in plant leaf growth under phosphorus limitation leads to the translocation of photosynthates to the roots in order to improve their development for better soil exploration. The biomass of bean pods was also highest for the co-inoculated treatments with both phosphorus sources (Table 3).

Co-inoculated plants retained more phosphorus compared to plants with individual inoculation and controls (Table 4). Likewise, co-inoculation improved the phosphorus concentrations of bean pots with both phosphorus sources (Table 4). The principal component analyses (PCA) revealed that all the measured parameters correlate with the first factor for faba bean plants (Fig. 2). Higher biomass and phosphorus concentrations corresponded to the co-inoculated treatments under both phosphorus sources (on the right). They are separated from the individual inoculation treatments of faba bean. The lower levels of these parameters (on the left) correspond to the uninoculated controls (Fig. 2). Several other studies show the positive effect of co-inoculation with rhizobia and different PGPR on plant growth and yield of lentils, bean, Vigna mungo and chickpea [29-32], indicating that plant growth promotion can be achieved by the selection of suitable strains. Success depends on several factors such as plant genotype and bacterial species used [33]. Plants have developed many mechanisms to adapt to phosphorus-deficient soils, which includes the secretion of phosphatases from roots [34]. This facilitates the hydrolysis of soil organic phosphate at lower $\mathrm{pH}$ and thereby increases the availability of orthophosphate [35]. To test, if this is also true for faba bean in our inoculation experiments, we measured phosphatase and phytase activities in the roots of plants under a different phosphorus supply. Indeed, inoculation with PGPR significantly increased the corresponding enzymatic activities - especially in roots supplemented with tricalcium phosphate (Table 4). Co-inoculation treatments yielded the highest values. Such a stimulation of phosphatase/phytase was reported for other plant/bacteria combinations. For example, Ramesh et al. [36] reported that several Bacillus isolates stimulated phosphatase and phytase activity in the soybean rhizosphere to different degrees. A dependency of phosphatase activity on the combination of Phaseolus vulgaris cultivars and rhizobial strains was found by Mandri et al. [13]. For Phaseolus vulgaris, it was shown that a low phosphorus level in the soil leads to an increase both the density and the activity of phytate-mineralizing bacteria [37]. Such a predisposition of bacteria to produce phosphatases would be an advantage for plants growing in phosphorous-deficient soils, as most of the beans are cultivated in Africa in phosphorus-deficient soils [38].

\section{Conclusions}

To improve soil fertility and plant growth, effective phosphate-solubilizing bacteria are a promising tool to maintain agricultural resources. We studied the impact of phosphate source and inoculation on faba bean growth, phosphate nutrition, and phosphatasephytase activities. The tested bacterial strains were able to mobilize insoluble phosphate and potassium and to produce important compounds for plant growth and nutrition such as auxins, siderophores, and exopolysaccharides. Inoculation of faba bean with these strains significantly improved plant length, shoot, root, and bean pod dry weight. Similarly, phosphorus concentrations in the plant and phosphatase/ phytase activities were increased. Highest values were obtained with co-inoculation treatments. The PCA analyses showed that the highest values of biomass, phosphorus concentrations, and enzymatic activities are attributed to the co-inoculated plants supplemented with tricalcium phosphate or irrigated with potassium phosphate $\mathrm{KH}_{2} \mathrm{PO}_{4}$. The ability of the studied strains to increase growth and productivity of bean plants - even in the presence of the insoluble form of phosphorus encourages their future use in agricultural practices. For validation of the results, studies under natural field conditions are necessary. This might lead to a reduced and optimized use of chemical fertilizer and thus ensure sustainable agricultural resources.

\section{Acknowledgements}

This work was partially supported by the Alexander von Humboldt foundation and project PPR2/2016/42, CNRST, Morocco.

\section{Conflict of Interest}

The authors declare there is no conflict of interest.

\section{References}

1. YADAV B., VERMA A. Phosphate solubilization and mobilization in soil through microorganisms under arid ecosystems. In: The functioning of ecosystems, Croacia Capítulo. ALI M. (ed). Pub: In Tech, 99, 2012.

2. ZHU J., LI M., WHELAN M. Phosphorus activators contribute to legacy phosphorus availability in agricultural soils: A review. Sci. Total Environ. 612, 522, 2018. 
3. KAMINSKY L.M., THOMPSON G.L., TREXLER R.V., BELL T.H., KAO-KNIFFIN J. Medicago sativa has reduced biomass and nodulation when grown with soil microbiomes conditioned to high phosphorus inputs. Phytobiomes J. 2 (4), 237, 2018.

4. HORN J.V., SARTORIUS C. Impact of supply and demand on the price development of phosphate (fertilizer). In: ASHLEY K, MAVINIC D., KOCH F. (eds.), International Conference on Nutrient Recovery from Wastewater Streams Vancouver. IWA Publishing, London, 45, 2009.

5. DANESHGAR S., CALLEGARI A., CAPODAGLIO A., VACCARI, D. The potential phosphorus crisis: resource conservation and possible escape technologies: A review. Resources. 7 (2), 37, 2018.

6. PRASAD R., KUMAR M., VARMA A. Role of PGPR in soil fertility and plant health. In: Plant-GrowthPromoting Rhizobacteria (PGPR) and medicinal plants. EGAMBERDIEVA D., SHRIVASTAVA S., VARMA A. (eds). Springer Cham: Heidelberg New York Dordrecht, London, 247, 2015.

7. GUPTA G., PARIHAR S.S., AHIRWAR N.K, SNEHI S.K., SINGH V. Plant Growth Promoting Rhizobacteria (PGPR): Current and future prospects for development of sustainable agriculture. J. Microb. Biochem. Technol. 7, 96, 2015.

8. AKHTAR N., ARSHAD I., SHAKIR M. A., QURESHI M. A., SEHRISH J., AL L. Co-inoculation with Rhizobium and Bacillus sp. to improve the phosphorus availability and yield of wheat (Triticum aestivum L.). J. Anim. Plant Sci. 23 (1), 190, 2013.

9. YADAV J., VERMA J. P. Effect of seed inoculation with indigenous Rhizobium and plant growth promoting rhizobacteria on nutrients uptake and yields of chickpea (Cicer arietinum L.). Eur. J. Soil Biol. 63, 70, 2014.

10. PÉRET B., DESNOS T., JOST R., KANNO S., BERKOWITZ O., NUSSAUME L. Root architecture responses: In search of phosphate. Plant Physiol. 166 (4), 1713, 2014.

11. WU L., KOBAYASHI Y., WASAKI J. AND KOYAMA H. Organic acid excretion from roots: a plant mechanism for enhancing phosphorus acquisition, enhancing aluminum tolerance, and recruiting beneficial rhizobacteria. Soil Sci. Plant Nutr. 64 (6), 697, 2018.

12. BALEMI T., NEGISHO K. Management of soil phosphorus and plant adaptation mechanisms to phosphorus stress for sustainable crop production: A review. J. Soil Sci. Plant Nut. 12 (3), 547, 2012.

13. MANDRI B., DREVON J.J., OUFDOU K., PLASSARD P., PAYRE H., BARGAZ A., GHOULAM C. Interactions between common bean (Phaseolus vulgaris) genotypes and rhizobia strains isolated from Moroccan soils for growth, phosphatase and phytase activities under phosphorus deficiency conditions. J. Plant Nutr. 35, 1477, 2012.

14. NAUTIYAL C.S. An efficient microbiological growth medium for screening phosphate solubilizing microorganisms. FEMS Microbiol. Lett. 170, 265, 1999.

15. BENIDIRE L., LAHROUNI M., DAOUI K., FATEMI Z., CARMONA R., GÖTTFERT M., OUFDOU K. Phenotypic and genetic diversity of Moroccan rhizobia isolated from Vicia faba L. and study of genes that are likely to be involved in their osmotolerance. Syst. Appl. Microbiol. 41, 51, 2018.

16. MAGHRAOUI T., BECHTAOUI N., GALIANA A., WAHBI S., DUPONNOIS R., HAFIDI M., DAOUI K., FATEMI Z.E.A., DE LAJUDIE P., OUFDOU K. Effect of inoculation by Moroccan rock phosphate solubilizing rhizobia, versus phosphorus fertilization, on the growth and the phosphorus uptake by Vicia faba. Pakistan J. Agric. Sci. 53, 817, 2016.

17. ALIKHANI H.A., SALEH-RASTIN N., ANTOUN $\mathrm{H}$. Phosphate solubilizing activity of rhizobia native to Iranian soils. Plant Soil. 287, 35, 2006.

18. SCHWYN B., NEILANDS J.B. Universal chemical assay for the detection and determination of siderophores. Anal. Biochem. 160, 47, 1987.

19. LEE V.T., MATEWISH J.M., KESSLER J.L., HYODO M., HAYAKAWA Y., LORY S. A cyclic-di-GMP receptor required for bacterial exopolysaccharides production. Mol. Microbiol. 65, 1474, 2007.

20. BANO N., MUSARRAT J. Characterization of a new Pseudomonas aeruginosa strain $\mathrm{NJ}-15$ as a potential biocontrol agent. Curr. Microbiol. 46 (5), 324, 2003.

21. ONYEZE R.C., ONAH G.T., IGBONEKWU C.C. Isolation and characterization of nitrogen-fixing bacteria in the soil. Int. J. Life Sci. Biotechnol. Pharma. Res. 2, 2250, 2013.

22. RIGAUD J., PUPPO A. Indole-3-acetic acid catabolism by soybean bacteroids. J. Genet. Microbiol. 88, 223, 1975.

23. OLSEN S., SOMMERS L.E. Phosphorus. In: Methods of soil analysis Part 2 Chemical and microbiological properties of phosphorus. PAGE A.L. (ed). American Society of Agronomy: Soil Science Society of America, Madison, 403, 1982.

24. ASMAR F., GISSEL-NIELSEN G. Extracellular phosphomono- and phosphodiesterase associated with and released by the roots of barley genotypes: A non-destructive method for the measurement of the extracellular enzymes of roots. Biol. Fert. Soils. 25, 117, 1997.

25. ASMAR F. Variation in activity of root extracellular phytase between genotypes of barley. Plant Soil. 195, 61, 1997.

26. INGLE K.P., PADOLE D.A. Phosphate solubilizing microbes: An overview. Int. J. Curr. Microbiol. Appl. Sci. 6, 844, 2017.

27. PRABHU N., BORKAR S., GARG S. Phosphate solubilization mechanisms in alkaliphilic bacterium Bacillus marisflavi FA7. Curr. Sci. 114 (4), 845, 2018.

28. ETESAMI H., MAHESHWARI D.K. Use of plant growth promoting rhizobacteria (PGPRs) with multiple plant growth promoting traits in stress agriculture: Action mechanisms and future prospects. Ecotoxicol. Environ. Saf. 156, 225, 2018.

29. SINGH N., SINGH G., AGGARWAL N., KHANNA V. Yield enhancement and phosphorus economy in lentil (Lens culinaris Medikus) with integrated use of phosphorus, Rhizobium and plant growth promoting rhizobacteria. J. Plant Nutr. 41(6), 737, 2018.

30. KORIR H., MUNGAI N.W., THUITA M., HAMBA Y., MASSO C. Co-inoculation effect of rhizobia and plant growth promoting rhizobacteria on common bean growth in a low phosphorus soil. Front. Plant Sci. 8,141, 2017.

31. QURESHI M.A., IQBAL A., AKHTAR N., SHAKIR M., KHAN A.Z. Co-inoculation of phosphate solubilizing bacteria and rhizobia in the presence of L-tryptophan for the promotion of mash bean (Vigna Mungo L.). Soil Environ. 31, 47, 2012.

32. VERMA J.P., YADAV J., TIWARI K.N., KUMAR A. Effect of indigenous Mesorhizobium spp. and plant growth promoting rhizobacteria on yields and nutrients uptake of chickpea (Cicer arietinum L.) under sustainable agriculture. Ecol. Eng. 51, 282, 2013. 
33. ABDI N., BARGAZ A., BOURAOUI M., LTAIEF B., GHOULAM C., SIFI B. Symbiotic responses to insoluble phosphorus supply in common bean (Phaseolus vulgaris L.): rhizobia symbiosis. Afr. J. Biotechnol. 11 (19), 4360, 2012.

34. LIU P., CAI Z., CHEN Z., MO X., DING X., LIANG C., LIU G., TIAN J. A root-associated purple acid phosphatase, SgPAP23, mediates extracellular phytate-P utilization in Stylosanthes guianensis. Plant Cell Environ. 41 (12), 2821, 2018.

35. DOTANIYA M.L., APARNA K., DOTANIYA C.K., SINGH M., REGAR K. L. Role of soil enzymes in sustainable crop production. In: Enzymes in food biotechnology, production, applications, and future prospects. KUDDUS M. (ed). Academic Press, Elsevier Inc, 569, 2019.
36. RAMESH A., SHARMA S.K., JOSHI O.P., KHAN I.R. Phytase, Phosphatase activity and P-nutrition of soybean as influenced by inoculation of Bacillus. Indian J. Microbiol. 51, 94, 2011.

37. MAOUGAL R.T., BRAUMAN A., PLASSARD C., ABADIE J., DJEKOUN A., DREVON J.J. Bacterial capacities to mineralize phytate increase in the rhizosphere of nodulated common bean (Phaseolus vulgaris) under $\mathrm{P}$ deficiency. Eur. J. Soil Biol. 62, 8, 2014.

38. JANSA J., BATIONO A., FROSSARD E., RAO I.M. Options for improving plant nutrition to increase common bean productivity in Africa. In: Fighting poverty in SubSaharan Africa: The multiple roles of legumes in integrated soil fertility management. BATIONO A., WASWA B., OKEYO J., MAINA F., KIHARA J., MOKWUNYE U. (eds). Springer, Dordrecht, 201, 2011. 
